\title{
Measuring The Impact Of Branded Alcohol Advertising And Price On Brand Versus Segment Consumption
}

\author{
Marlize Terblanche-Smit; University of Stellenbosch Business School, South Africa \\ Ronel du Preez; Stellenbosch University, South Africa \\ Tiaan van der Spuy; University of Stellenbosch Business School, South Africa
}

\begin{abstract}
Branded advertising, a foundation of brand-building efforts, seek to persuade consumers to select a specific brand over a competitor brand. The objective of this study was to examine the effectiveness of branded advertising in the alcoholic beverage industry of South Africa, particularly with regard to the relationship between alcohol advertising, price effects and alcohol consumption (brand and segment). A causal research design was used, which included secondary data analysis (SDA) and quantitative time series data analysis spanning a 32 months period. Variables included brand advertising expenditure; -sales volume; -market share; -retail selling price (RSP); and segment volume. Tests for stationarity, co-integration and regression were applied to assess associations between constructs. The findings indicate that branded alcohol advertising had little or no effect on brand-and segment consumption, or brand market share whereas price effects were significant. Limitations include the scope of the time series of data and the exclusion of below-the-line advertising expenditure. Notwithstanding, this paper provides evidence to support the imperative of the integrated marketing mix and optimal combination of marketing mix elements.
\end{abstract}

Keywords: Alcohol Marketing; Alcohol Advertising; Alcohol Consumption; Consumer Behavior

\section{INTRODUCTION}

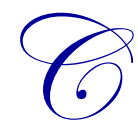

ompanies spend millions of dollars annually on advertising in an effort to differentiate their brands and to persuade consumers to choose their brands over that of their competitors. The South African liquor industry is no different and is characterised by intense product rivalry and substantial expenditure on advertising. According to the latest AdDynamix (Advertising expenditure) data an estimated \$165 million was spent on liquor advertising in 2011 alone) (AdDynamix, 2011). These amounts only represents above-the-line (ATL) advertising expenditure, meaning mass media space that is bought by the advertiser (AdDynamix, 2011). Below-theline (BTL) advertising, which includes amongst others, consumer and sales promotions (Belch \& Belch, 2012), are excluded from these amounts. Ultimately, companies that operate in the alcoholic beverage market must determine whether their expenditure on advertising is justified and if in fact it contributes toward their own brands consumption, market share gains, and the ability to differentiate, or also contribute to the total segment consumption levels.

The focus of this study was to examine the effectiveness of advertising in the alcoholic beverage industry of South Africa, particularly with regard to the relationship between alcohol advertising, price effects and alcohol consumption. Therefor the study investigated whether brand-level alcohol advertising and price effects causes an increase in consumption of alcohol per se, or whether it only increases brand market share and brand-level consumption of the specific brands advertised. This is important for the companies that operate in the market as the findings may assist them to determine whether their existing expenditure on advertising is justified, i.e. how much advertising is contributing toward their market share gains/losses. 


\section{Background And Theoretical Perspectives}

\section{Branded Advertising}

Advertising is a means by which a brand can build relationships with consumers and the key purpose of advertising is to inform, persuade and remind consumers about the brands that companies offer (brand awareness). Marketers are constantly faced with the challenge to build brand awareness both economically and efficiently in the minds of consumers. Advertising further plays a significant role in the process of developing and sustaining brand equity (Buil, de Chernatony \& Martínez, 2013; Chaudhuri, 2002; Huang, \& Sarigöllü, 2012; Kotler \& Keller, 2012; Valette-Florence, Guizani \& Merunka, 2011). Consumers need information to be able to choose between alternative brands (Terui, Ban \& Allenby, 2011) and advertising assists to establish beliefs about the attributes and general image of a brand/product (Laforet 2010; Maehle \& Supphellen, 2013). Ensuing, consumers are bombarded with marketing messages about brands (McKay-Nesbitt, Manchanda, Smith \& Huhmannet, 2011). Increased marketing messages and large advertising budgets however do not make an advertisement successful; advertising can only succeed if advertisements gain attention through creative execution, media selection and if the brands that are advertised are remembered (Buil, de Chernatony \& Martínez, 2013; Kotler, Armstrong, Wong \& Saunders, 2008).

\section{The South African Liquor Market}

In a mature market such as the South African liquor market the advertising strategy is primarily focussed on increasing market share through increased brand awareness, increased brand commitment and increased repeat purchases (ARA, 2013). In order to reach these aims and to bolster brand differentiation, companies continue to spend substantial amounts on branded advertising. According to Dovy (2013), total above-the-line advertising spent in South Africa (SA) during 2011 was \$ 3.2 billion. If one adds the below-the-line advertising and sponsorships to this figure the amount rises to a staggering $\$ 4.4$ billion (2011). The SA liquor industry's advertising spend was estimated at \$165 million (above-the-line) in 2011 (AdDynamix, 2011). Ultimately the key question that needs to be asked by companies in the alcohol industry is whether the large expenditure on advertising is justified in terms of market share gains. Conversely, the policy makers in their quest to curb alcohol abuse and the socio-economic threats that accompany alcohol abuse in South Africa need to determine the impact of branded alcohol advertising on total alcohol consumption (Anderson, de Bruijn, Angus, Gordon, Hastings, 2009; Economic impact of an advertising ban on alcoholic beverages, 2013). To put it differently, does branded alcohol advertising influence individuals to consume more alcohol?

\section{The Alcohol Advertising Debate: Consumption And Price}

For many years there has been an on-going debate concerning advertising effectiveness in the alcoholic beverage market, and the effect that advertising has on the demand for alcoholic beverages. A number of health related organisations, including the World Health Organisation, called for advertising control as a key part of their anti-alcohol campaigns, including voluntary codes and content guidelines to outright bans on alcohol advertising as imposed in countries like Sweden, Denmark, Finland, Norway and Ireland (WHO, 2011). In South Africa a possible ban of alcohol advertising as a measure to reduce alcohol consumption and abuse is an issue which has, in recent years, elicited fierce debate amongst many of the stakeholders in the alcoholic beverage industry (Seggy, 2012). It is believed by many in the industry that stricter regulation would be the logical next step for government (Euromonitor International, 2011a).

There are however opposing views regarding the effects of advertising on alcohol consumption and abuse. Many health professionals and consumer groups contend that there is substantial evidence to support the proposition that alcoholic beverage firms advertise in order to increase the size of the alcoholic beverage market and that advertising creates positive images of alcohol consumption and thus, increases the overall demand for alcohol. They further argue that advertising may increase price competition, which makes alcohol beverages more affordable to consumers and therefore, increases their propensity to consume (Gius, 1996). Various authors (Anderson, de Bruijn, Angus, Gordaon \& Hastings, 2009; Parry, Burnhams \& London, 2012; Snyder, Milici, Slater, Sun \& Strizhakova, 2006) argue that evidence suggests that alcohol advertising does not only influence brand choice but that it influences young people's behaviour in that it encourages positive beliefs about drinking, earlier onset of drinking 
behaviour in larger quantities as well as the normalization of drinking in different settings. Ramsoomar \& Morojele (2012) emphasises the detrimental health and social effects of alcohol on the youth and cite evidence that alcohol advertising deliberately targets the youth. In an overview of thirteen longitudinal studies that included over 38000 youth, Anderson et al., (2009) conclude that alcohol advertising and promotion does increase the likelihood that adolescents will consume alcohol at an earlier age and consume more alcohol (if they are already doing so).

Conversely, stakeholders in the alcoholic beverage industry, however, maintain that advertising does not increase total consumption. They argue that advertising only results in brand switching within the industry, with little or no effect on total consumption. They also contend that advertising serves to differentiate products and/or promote product quality, resulting in higher prices which decreases consumers' propensity to consume, and increases their sensitivity to the price of alcoholic beverages (Nelson \& Young, 2001). Sensitivity to the price of a product, referred to as price elasticity, is reflected in market sales or share and is the response of consumers to purchase a specific product based on increased or decreased market prices. Typically price sensitivity is less in the early stages of a product's life cycle, possibly because of limited consumer information about the price of a product. During the growth and maturity phases of a product's life cycle consumers are relatively informed and more sensitive to differences in prices. Essentially high price sensitivity, should not encourage marketing practitioners to allocate expenditure from advertising to price discounting (Walters, 2006; Dekimpe, Hanssens \& Silva-Risso, 1999; Bronnenberg \& Wathieu, 1996; Tellis, 1988). The marketing and promotional mixes have to be selected carefully, since the application thereof changes over a product's life cycle. Marketers have to decide which promotional mix is most appropriate for each phase of a product's life cycle. During the maturity phase of a product's life cycle it would essentially be more important to defend market share, increase profits or remind consumers of a brand (Bronnenberg \& Wathieu, 1996; Blattberg, Briesch \& Fox, 1995).

Stakeholders in the alcoholic beverage industry contend that most of the alcohol consumed in South Africa is not branded advertised products, but rather illicitly home-brewed alcohol products (as in other developing countries world-wide). The price differentiation between the home-brewed products and advertised branded alcoholic products make branded products generally inaccessible to a large proportion of the population (including the youth) as excise taxes add to the price differential and increases price sensitivity Further to this, home-brewed products are unlawful, leading to the use of low quality raw materials that could be contaminated and as a result contribute to health risks (which is not the case in branded beverages). The ARA report (Economic impact of an advertising ban on alcoholic beverages, 2013) contends that the majority of the drinking population in South Africa (youth included) consumes alcohol that is not commercially marketed or advertised. According to Fisher (1999), Duffy (1995, 1991), Nelson (2010), Nelson and Moran (1995), and Calfee and Scheraga (1994), there has been insufficient evidence to indicate that alcohol advertising increases levels of aggregate consumption among consumers. Ellickson, Colling, Hambarsoomians \& McCaffery (2005) concede that various forms of alcohol advertising could influence adolescent drinking, but that the dominant source is dependent on the adolescent's previous experience with alcohol. Their results indicated that television beer advertising were not a significant predictor of drinking in both drinking and non-drinking grade 7 youths; whereas in-store advertising (beer) and (beer) concessions stands at music festivals and sport events predicted frequency of grade 9 drinking. However, alcohol consumption is further influenced by a vast array of variables for example the positive affect of per capita income, tourism and a measure of drinking sentiment and negatively affected by the real price of alcohol (Nelson, 2010; Nelson \&Young, 2001).

Based on the abovementioned information, one might be inclined to ask the question: "Why then advertise?" Research conducted by Nelson (1999), Gius (1996), and Lee and Tremblay (1992) concluded that advertising does have an assessable effect on market share for individual brands as well as a substitution effect between brands. Their theory suggests that there are essentially two effects of brand-level advertising: firstly, an increase in the demand for the advertised brand at the expense of competitor brands (own effect); and secondly an increase in demand for all brands (market wide expansion effect or market effect). The authors (Nelson, 1999; Gius, 1996; Lee \& Tremblay, 1992) concluded that the own- and market effects of advertising are likely to simultaneously influence most markets where products are advertised. Their research states that, in a given market, when the own effect is stronger than the market effect it is an indication that advertising results only in brand switching within that market. When the opposite is true, it is an indication that advertising increases the overall size of that market. The latter is also referred to as primary demand stimulation. Primary demand stimulation creates demand for an entire 
product category, and can be due to a range of factors, which can include new consumers entering a product category or an increase in consumption by current consumers. Advertising is regularly used to create selective demand for a specific brand, where advertising serves to increase the value of a particular brand compared to competition, therefore most marketing practitioners concentrate on selective demand. The primary demand component is however also important, since growth in primary demand enlarges the total market and product category. Advertising campaigns that draw new buyers to a product category can have an extended effect when certain consumers become regular users of a specific brand within the product category. When constant primary demand conditions exist companies can build an advantage over the competition by encouraging consumers to switch to their brand (Walters, 2006; Dekimpe, Hanssens \& Silva-Risso, 1999).

Ensuing from the theoretical perspectives, the following hypotheses were formulated:

H1:A brand's advertising expenditure has a positive effect on the amount of litres (volume) that are consumed of that brand.

H2: A brand's advertising expenditure has little or no effect on the total amount of litres (volume) that are consumed in that brand's liquor segment

H3: Alcohol advertising affects the market share of alcoholic brands positively, relative to the total alcoholic beverage market.

H4: A brand's retail selling price (RSP) has a negative effect on the amount of litres that are consumed of that brand.

\section{RESEARCH METHOD}

A causal research design was used for the purposes of this study. The data analysis included secondary data analysis (SDA) using quantitative time series data over a 32 month period. The mode of observation was longitudinal (monthly) (Saunders, Lewis \& Thornhill, 2009). Brands within the following product categories were researched: beer, spirits, ciders and ready-to-drink flavoured alcoholic drinks. In South Africa, the aforementioned segments are the most popular alcoholic beverage categories amongst the youth (Brand Health Monitor, 2008). Market data used included AC Nielsen (volume and value/price), alcohol company sales information, and AdDynamix (advertising spend per brand and liquor segment) spanning a 32 month period. The data was based on market estimates compiled by AC Nielsen Research and was supplied by a prominent producer in the South African liquor industry. The variables contained within the original data set represented primary market indicators in the liquor industry which included sales volume, sales value and advertising expenditure of the brands being investigated. The period of observation was 32 months (from January 2007 until August 2009). Adjustments were made to the time series variables before it could be tested, sales volume (expressed in litres), was subdivided into 'segment volume' and 'brand volume' in order to observe the own- and market effects of advertising on the relevant brands and/or the liquor segments within which they exist. Subsequently, this adjustment allowed for the extrapolation of each brand's market share based on the amount of litres sold by the brand relative to the total amount of litres sold in the entire liquor segment. The liquor industry is valued according to retail selling price (RSP), which is the sales price of liquor at off-trade establishments only. Each brand's retail selling price (RSP) was converted from the measurement unit 'per pack' to 'per litre' in order to establish 'litre' as the common denominator in the analysis. Advertising expenditure was indicated in SA Rands. The data used to calculate the industry sales volume was based solely on measurements by AC Nielsen Research from off-premise establishments' sales (such as wholesale and retail liquor stores, which accounted for $70.3 \%$ of total liquor sales volume) and did not take into account sales at on-premise establishments such as bars, restaurants, clubs and other drinking establishments. Offpremise figures tend to be a more accurate reflection of actual sales volumes as it excludes the possibility of double counting. Advertising expenditure estimates were sourced from AdDynamix, an AC Nielsen Media Research tool that primarily measures above-the-line (ATL) advertising. The data spanned a period of economic downturn, which could have influenced the price of alcoholic beverages and ultimately consumption. During periods of economic downturn brand purchasing behaviour can be affected, which can lead to shifts in market share. However, history suggests that periods of economic decline can sometimes cause weaker brands to fail, while further strengthening category leaders. Additionally past research confirmed that the effect a recession will have on a specific brand could also be directly related to the category to which it belongs (Bowmer, 2011). 
The following variables were observed in the data analysis: i) brand sales volume; ii) segment sales volume; iii) weighted retail selling price per litre (wRSP/l); iv) market share; and v) advertising expenditure. Due to confidentiality the two brands used in the final analysis are referred to as Brand $M$ (mainstream) and Brand $P$ (premium). Both brands were among the top 50 most valuable and strongest brands in SA during the period of investigation. Brand strength is an index scored summarising the performance of the brand on a number of quantitative (economic performance) and qualitative (brand equity) measures vs its competitors (Brand Finance, 2012).

The data analysis comprised the use of standard statistical techniques which assessed the relationships between a selection of time series variables contained within the data set. Statistical analysis included tests for stationarity and co-integration, the latter was executed by means of fitting co-integration regression models on paired unit root non-stationary variables in order to test the stationarity of their residuals (Malhotra \& Birks, 2007; Unger, Schuster, Dent \& Stacy, 2003). When time series variables are found to be unit root non-stationary, the regression relationship between them can only be established once the relevant paired variables are found to be cointegrated. Hence, a co-integration regression was fitted on a selection of paired unit root non-stationary variables for both Brand $\mathrm{M}$ and Brand $\mathrm{P}$, and the residuals produced from these regressions were tested for stationarity. The stationarity results for the relevant paired variables were obtained from Dickey-Fuller unit root tests. The significance of each paired relationship is revealed in the results obtained from the relevant co-integration regressions. If the residuals produced from these regressions are stationary (i.e. if $p<0.05$ ), it implies that the relevant paired variables are co-integrated and that the regressions performed on them are valid (Malhotra \& Birks, 2007; Unger, Schuster, Dent \& Stacy, 2003). Regression analyses were performed to assess the relationships between a selection of time series variables, namely advertising expenditure and retail selling price (RSP) measures with measures of alcohol use.

\section{MAJOR FINDINGS}

The stationarity results of the Dickey-Fuller unit root test for the two sets of time series variables (Brand M and Brand P) indicated thatall the variables were unit root non-stationary (i.e. $\mathrm{p}>0.05$ ), except for Brand M's advertising expenditure $(\mathrm{p}<0.01)$.

A co-integration regression was fitted on a selection of paired unit root non-stationary variables for both Brand $\mathrm{M}$ and Brand $\mathrm{P}$, and the residuals produced from these regressions were tested for stationarity. In Brand M's case, the variable advertising expenditure was found to be stationary and, therefore, it was not tested against the non-stationary variables brand volumes and market share. Although the variable segment volumes was found to be non-stationary, it reacted stationary and was found to be co-integrated with advertising expenditure $(\mathrm{p}<0.05)$. The variable, weighted RSP per litre (wRSP/l), was co-integrated with the variables brand volumes, segment volumes and market share, implying that the regression relationship between the relevant paired variables can be determined. Finally, the variable market share was co-integrated with a combination of the independent variables weighted RSP per litre and advertising expenditure. In Brand P's case the variable weighted RSP per litre was co-integrated with the dependent variables brand volumes, segment volumes and market share. Advertising expenditure was cointegrated with each of the three dependent variables that it was paired with, namely market share, brand volumes and segment volumes. The residuals produced from these regressions were stationary $(\mathrm{p}<0.01)$, which implied that the relevant paired variables was co-integrated and that the regressions performed on them were valid.

The valid regression results of the dependent variables market share, brand volumes and segment volumes measured against the independent variables advertising expenditure and weighted RSP per litre for Brand $\mathrm{M}$ and Brand $\mathrm{P}$ were specified, and the models were subsequently interpreted (these are not reported here). Table 1 presents a summary of the regression results. Advertising expenditure as an independent variable was not significant in any of the regression models and explained very little of the variation in brand volumes, segment volumes and market share. RSP per litre as an independent variable was significant to all of the regression models and explained a large percentage of the variation in brand volumes, segment volumes and market share. In all instances RSP per litre had an inverse linear regression relationship with the three dependent variables, implying that an increase in the price per litre reduces brand volumes, segment volumes and market share. Price effects were significant, explaining between 
$48 \%$ and $56 \%$ of the variation in brand volume, between $21 \%$ and $31 \%$ of the variation in market share, and between $22 \%$ and $24 \%$ of the variation in segment volumes

Table 1: Summary Of Regression Results

\begin{tabular}{|c|c|c|c|c|c|}
\hline & & Brand M & & Brand $P$ & \\
\hline Dependent Variable & $\begin{array}{c}\text { Independent } \\
\text { Variable }\end{array}$ & Significance & $\begin{array}{l}\text { Variation } \\
\text { Explained }\end{array}$ & Significance & $\begin{array}{l}\text { Variation } \\
\text { Explained }\end{array}$ \\
\hline \multirow[t]{2}{*}{ Brand Volumes } & $\begin{array}{l}\text { Advertising } \\
\text { expenditure }\end{array}$ & Not co-integrated & $*$ & Not significant & $*$ \\
\hline & RSP per litre & Highly significant & $55.83 \%$ & Highly significant & $47.84 \%$ \\
\hline \multirow[t]{2}{*}{ Segment Volumes } & $\begin{array}{l}\text { Advertising } \\
\text { expenditure }\end{array}$ & Not significant & $*$ & Not significant & $*$ \\
\hline & RSP per litre & Significant & $22.18 \%$ & Significant & $24.29 \%$ \\
\hline \multirow[t]{2}{*}{ Market Share } & $\begin{array}{l}\text { Advertising } \\
\text { expenditure }\end{array}$ & Not co-integrated & $*$ & Not significant & $*$ \\
\hline & RSP per litre & Significant & $20.56 \%$ & Significant & $31.35 \%$ \\
\hline
\end{tabular}

Based on the findings the following conclusions can be drawn regarding the hypotheses formulated:

H1 is rejected, implying that a brand's advertising expenditure has little or no effect on the amount of litres (volume) that are consumed of that brand.

$\mathrm{H} 2$ is accepted, implying that a brand's advertising expenditure has little or no effect on the total amount of litres (volume) that are consumed in that brand's liquor segment.

$\mathrm{H} 3$ is rejected, implying that alcohol advertising has little or no effect on the market share of the alcoholic brands being advertised.

$\mathrm{H} 4$ is accepted at the $95 \%$ significance level, implying that a brand's retail selling price (RSP) does have a negative effect on the amount of litres that are consumed of that brand.

\section{DISCUSSION, IMPLICATIONS AND CONCLUSIONS}

The findings from this study suggest that over the 32-month period measured, the branded advertising expenditure of alcoholic beverages in the SA liquor industry had little or no effect on consumption, providing support for the findings of Fisher (1999), Duffy (1995, 1991), Nelson and Moran (1995), as well as Calfee and Scheraga (1994). The percentage variation in brand volumes, segment volumes and brand market share explained by branded advertising was non-significant, partially contradicting the findings of Parry, Burnhams and London (2012); Anderson, de Bruijn, Angus, Gordaon and Hastings (2009) as well as Snyder, Milici, Slater, Sun and Strizhakova (2006) who argued that evidence suggests that alcohol advertising does not only influence brand choice but also young people's behaviour and increased consumption.

The retail selling price (RSP) of alcoholic beverages had a significant effect on consumption and explained between $47.8 \%$ and $55.8 \%$ of the variation in brand volumes, which supports the findings of Gius (1996), who stated that advertising may increase price competition, which makes alcohol beverages more affordable to consumers and consequently, increases their propensity to consume. The influence of RSP on brand volume, as well as the effect of RSP on brand market share, which explained between $20.6 \%$ and $31.4 \%$ of the variation in market share, supports the concept of selective demand. There seems to be overall high price sensitivity towards the brands measured in this research study (Walters, 2006; Dekimpe, et al., 1999). The percentage variation in segment volumes explained by RSP ranged between $22.2 \%$ and $24.3 \%$. The latter underlines the effect of RSP on primary demand stimulation, and the overall high price sensitivity within this product category (Walters, 2006; Dekimpe, et al., 1999; Tellis, 1988). It is also probable that with lower brand or segment prices consumers moved from home-brewed products to a down-market brand. The smaller price differentiation between home-brewed products and advertised branded alcoholic products could make branded products more accessible to a large proportion of the population, the opposite of what is expected by the Industry Association for Responsible Alcohol Use (ARA) (2013). It is important 
to note that a brand's advertising expenditure and price are just two of many variables that may influence that brand's sales volumes and selective demand. In addition to these variables probably the only 'influencers' of sales volumes that a brand is able to control is the product itself and distribution or availability, namely the key marketing mix variables. Sales volumes may also be influenced by factors such as per capita (or disposable income), drinking sentiment, unemployment, and the advertising expenditure and retail selling price of competitor brands, all factors that are generally beyond the control of the brand.

Although the findings of this study imply that advertising may not be the most effective marketing tool when a company's primary objective is to increase sales volumes or market share, it can be postulated that advertising might be too far removed from the point of purchase to influence sales directly? Advertising's primary role is to improve brand attitudes, loyalty, and image. If branded liquor producers want to increase brand sales volume it would be of value to review the total integrated marketing mix to ascertain the optimal mix of elements that should be included to increase sales volume (e.g. promotions) and improve attitudes and brand loyalty (e.g. advertising). Furthermore it is important to view the relationship between a brand's marketing expenditure and market performance from a long-term and short-term perspective. This fuels the on-going debate about the optimal marketing mix and whether advertising actually works, in other words increase sales volume or market share. Ultimately, companies in the alcoholic beverage market have to determine whether their expenditure on advertising is justified and contribute toward their own brand's consumption, market share gains, and their ability to differentiate their brand (selective demand) within the total market category (primary demand). It is also imperative to determine whether brand price promotions have long-term effects or only induce short-term brand switching (Walters, 2006; Tellis, 1988). Although consumers today are well informed and responsive to advertising and price differences, the high price sensitivity of primary and selective demand in the alcoholic beverage market should not prompt marketing practitioners into any drastic reallocation of advertising expenditure to price discounting. Additionally the marketing mix of brands in the alcoholic beverage market should be viewed in lieu of product life cycles, and marketing practitioners have to apply different marketing mix elements appropriately for each phase of the product life cycle. Limitations of this study include that data spanned a 32 month period of economic downturn; this could have influenced the price of alcoholic beverages and ultimately consumption. Additionally, advertising expenditure figures represented only above-the-line (ATL) expenditure. Future studies could investigate data over a longer observation period and also include the effect of the economic situation, and competitor brands on consumer consumption of alcoholic beverages, to illustrate the market and brand effects of advertising.

\section{AUTHOR INFORMATION}

\section{Marlize Terblanche-Smit}

She is a senior lecturer in marketing management at the University of Stellenbosch Business School and also Head of the MBA programme. Marlize has extensive industry experience in Marketing Strategy and Marketing Communication and practiced in the FMCG industry for more than 15 years. She served in various executive Marketing positions in the FMCG industry in South Africa. She also lectured Marketing management, Strategy and Marketing Communication at graduate and post-graduate level for many years. E-mail: Marlize.Terblanche$\underline{\text { Smit@usb.ac.za }}$

\section{Ronel du Preez}

Ronel du Preez is the Vice-Dean (Teaching) at the Faculty of Economic and Management Sciences and Professor at the Department of Industrial Psychology at Stellenbosch University. Her teaching and research expertise falls primarily within the field of Consumer Behaviour. Ronel received recognition for excellence in teaching and she is an NRF graded researcher. She acts as subject-editor for the South African Journal of Industrial Psychology and has published numerous peer-reviewed articles and presented several papers at international conferences in the field of

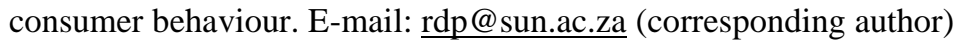

\section{Tiaan van der Spuy}

Tiaan completed his graduate and post-graduate studies at Stellenbosch, specializing in Marketing and Business Management. He worked in the advertising industry in South Africa for many years on a number of leading brands, which included some of the key alcoholic brands. He has extensive experience in marketing - and advertising 
strategy. Tiaan has completed research projects in the alcoholic beverage market. He is currently involved in the strategic business consulting industry. E-mail: tiaanvdspuy@gmail.com

\section{REFERENCES}

1. AdDynamix. (2011). Advertising Spend Data, Homepage. Retrieved September 17, 2011, from http://www.Ad dynamix.co.za

2. Anderson, P., De Bruijn, A., Angus, K., Gordon, R., \& Hastings, G. (2009). Impact of alcohol advertising and media exposure on adolescent alcohol use: a systematic review of longitudinal studies. Alcohol and Alcoholism, 44(3), 229-243.

3. Industry Association for Responsible Alcohol Use (ARA). (2009). Department of Social Development, Retrieved August 28, 2013, from http://ara.co.za

4. Industry Association for Responsible Alcohol Use (ARA). (2013). Economic impact of an advertising ban on alcoholic beverages. Econometrix Report for Industry Association for Responsible Alcohol, Retrieved March 14, 2014, from http://www.ara.co.za/uploads/ban-onalcoholadvertising/economic\%20Impact\%0of2\%20 an\%20Ad\%20Ban_20 Ban.

5. Belch, G.E. \& Belch, M.A. (2012). Advertising and promotion: An integrated marketing communications perspective . (9th ed.). New York: McGraw-Hill/Irwin.

6. Blattberg, R.C., Briesch, R. \& Fox, E.J. (1995). How promotions work. Marketing Science, 14, 122-132.

7. Bowmer, R. (2011). The Effects of the Recession on Brand Loyalty and "Buy Down" Behavior. Retrieved May 2, 2013, from http://www.comscore.com_OCTOBER 2011_update

8. $\quad$ Brand Finance. (2012). SA Top 50: 2012, Retrieved June 18, 2013, from http://www.brandsouthafrica.com/images/pdfs/southafica 50mostvaluable_brands_fin.pdf

9. Brand Health Monitor. (2008). Strategic brand analysis, February, 1-11.

10. Bronnenberg, B.J. \& Wathieu, L. (1996). Asymmetric promotion effects and brand positioning. Marketing Science, 15, 379-394.

11. Buil, I., de Chernatony, L., \& Martínez, E. (2013). Examining the role of advertising and sales promotions in brand equity creation. Journal of Business Research, 66(1), 115-122.

12. Calfee, J. \& Scheraga, C. (1994). The influence of advertising on alcohol consumption: A literature review and an econometric analysis of four European nations, International Journal of Advertising, 13(4), 287-310.

13. Chaudhuri, A. (2002). How brand reputation affects the advertising-brand equity link. Journal of Advertising Research, 42(3), 33-43.

14. Dekimpe, M.G., Hanssens, D.M. \& Silva-Risso, J.M. (1999). Long-run effects of price promotions in scanner markets, Journal of Econometrics, 89, 269-291.

15. Dovy, J. (2013). OMD Media Facts: South Africa and SADC Media Facts 2013. Retrieved August 28, 2012, from http://www.omd.co.za/media_facts/FOM029_Blueprint_OMD_mediafacts2013.pdf.

16. Duffy, M. (1995). Advertising in demand systems for alcoholic drinks and tobacco: a comparative study, Journal of Policy Modeling, 17(6), 557-577.

17. Duffy, M. (1991). Advertising and the consumption of tobacco and alcoholic drink: a system-wide analysis, Scottish Journal of Political Economy, 38(4), 369-385.

18. Ellickson, P. L., Collins, R. L., Hambarsoomians, K. \& McCaffrey, D. F. (2005). Does alcohol advertising promote adolescent drinking? Results from a longitudinal assessment. Addiction, 100(2), 235-246.

19. Euromonitor International. (2011). Country Market Insights: Alcoholic Drinks - South Africa, March, 117.

20. Fisher, J.C. (1999). Prevention and Societal Impact of Drug and Alcohol Abuse. Mahwah, New York: Lawrence Erlbaum Associates.

21. Fisher, J.C. \& Cook, P.A. (1995). Advertising, Alcohol Consumption, and Mortality: An Empirical Investigation. Westport, CT: Greenwood Press.

22. Gius, M.P. (1996). Using panel data to determine the effect of advertising. Journal of Studies on Alcohol, 57(1), 73.

23. Huang, R. \& Sarigöllü, E. (2012). How brand awareness relates to market outcome, brand equity, and the marketing mix. Journal of Business Research, 65(1), 92-99.

24. Kotler, P. \& Keller, K.L. (2012). Marketing Management (14th ed.). New Jersey: Pearson Education. 
25. Kotler, P., Armstrong, G., Wong, V.W.Y. \& Saunders, J.A. (2008). Principles of Marketing, 5th European ed., Harlow, U.K.: Prentice Hall.

26. Laforet, S. (2010). Managing brands: A contemporary perspective, McGraw-Hill Education, Berkshire, UK.

27. Lee, B. \& Tremblay, V.J. (1992). Advertising and the US market demand for beer, Applied Economics, 24(1), 69.

28. Malhotra, N.K. \& Birks, D.F. (2007). Marketing research: An applied approach (3rd ed.). London: Prentice Hall.

29. Maehle, N., \& Supphellen, M. (2013). Advertising strategies for brand image repair: The effectiveness of advertising alliances. Journal of Marketing Communications, 1-13. DOI: 10.1080/13527266.2013.866594

30. McKay-Nesbitt, J., Manchanda, R.V., Smith, M.C. \& Huhmann, B.A. (2011). Effects of age, need for cognition, and affective intensity on advertising effectiveness, Journal of Business Research, 64(1), 12-17.

31. Nelson, J.P. \& Young, D.J. (2001). Do advertising bans work? An international comparison. International Journal of Advertising, 20(3), 273-296.

32. Nelson, J.P. (1999). Broadcast Advertising and U.S. Demand for Alcoholic Beverages. Southern Economic Journal, 65(4), 774-790.

33. Nelson, J.P. (2010). What is learned from longitudinal studies of advertising and youth drinking and smoking? A critical assessment. International Journal of Environmental Research and Public Health, 7(3):870-926.

34. Nelson, J.P. \& Moran, J.R. (1995). Advertising and US alcoholic beverage demand: System-wide estimates. Applied Economics, 27(12), 1225.

35. Parry, C., Burnhams, N.H., \& London, L. (2012). A total ban on alcohol advertising: Presenting the public health case. South African Medical Journal, 102(7), 602-604.

36. Ramsoomar, L. \& Morojele, N.K. (2012). Trends in alcohol prevalence, age of initiation and association with alcohol-related harm among South African youth: Implications for policy. South African Medical Journal, 102(7), 609-612.

37. Seggie, J. (2012). Alcohol and South Africa's Youth. South African Medical Journal, 102(7), 587.

38. Smith, L. A., \& Foxcroft, D. R. (2009). The effect of alcohol advertising, marketing and portrayal on drinking behaviour in young people: systematic review of prospective cohort studies. BMC Public Health, $9(1), 51$.

39. Snyder, L. B., Milici, F. F., Slater, M., Sun, H., \& Strizhakova, Y. (2006). Effects of alcohol advertising exposure on drinking among youth. Archives of Pediatrics and Adolescent Medicine, 160(1), 18-24.

40. Tellis, G.J. (1988). The Price Elasticity of Selective Demand: A Meta-Analysis of Sales Response Models. Journal of Marketing Research, 25(4), 88-105.

41. Terui, N., Ban, M., \& Allenby, G. M. (2011). The effect of media advertising on brand consideration and choice. Marketing Science, 30(1), 74-91.

42. Unger, J.B., Schuster, D., Zogg, J., Dent, C.W. \& Stacy, A.W. (2003). Alcohol Advertising Exposure and Adolescent Alcohol Use: A Comparison of Exposure Measures. Addiction Research \& Theory, 11(3), 177 193.

43. Valette-Florence, P., Guizani, H., \& Merunka, D. (2011). The impact of brand personality and sales promotions on brand equity. Journal of Business Research, 64(1), 24-28.

44. Walters, D. (2006). Effectiveness and efficiency: the role of demand chain management. The International Journal of Logistics Management, 17(1), 75-94.

45. World Health Organisation (WHO). (2011). Global status report on alcohol and health, World Health Organisation, Geneva, 1-286. 


\section{NOTES}

